\title{
環境調和型合成反応を指向した水中ラジカル反応の開発
}

\author{
上田昌史
}

\section{Development of Radical Reactions in Water Aimed at Environmentally Benign Synthetic Reactions}

\author{
Masafumi UEDA \\ Kobe Pharmaceutical University, 4-19-1 Motoyamakita, Higashinada, Kobe 658-8558, Japan
}

(Received March 17, 2004)

\begin{abstract}
The aqueous medium radical reactions of a variety of imine derivatives such as oxime ether, oxime, hydrazone, nitrone, and $N$-sulfonylimine were investigated. Triethylborane-mediated intermolecular alkyl radical addition to glyoxylic oxime ether, oxime, and nitrone in water proceeded smoothly to give $\alpha$-amino acid derivatives in good yields. Alkyl radical addition to $N$-sulfonylimine proceeded in aqueous media using zinc as a radical initiator. The zinc-mediated radical reaction of the hydrazone with a chiral camphorsultam provided the corresponding alkylated products with good diastereoselectivities, which could be converted into enantiomerically pure $\alpha$-amino acids. The indium-mediated radical reactions provide new opportunities for carbon-carbon bond formation such as alkylation reactions of imines and 1,4addition to electron-deficient olefins. The indium-mediated tandem reactions also proceeded effectively via two carboncarbon bond-forming processes for the preparation of various types of functionalized cyclic compounds.
\end{abstract}

Key words_— radical reaction; aqueous media; oxime ether; indium; environmentally benign reactions

\section{1. はじめに}

近年, ラジカル反応は, 厳密な無水条件や脱酸素 条件を必要とせず，穏和な条件下で炭素一炭素結合 を形成できる手法として活発に研究され始め た. 1-8) しかし，その多くの研究が毒性の高いスズ ヒドリド試薬を用いており, ラジカル反応のさらな る発展のためには, スズヒドリドに依存しない反応 の開発が不可欠だと考えられている. 特に，イミン 類のラジカル反応においてスズヒドリドを用いた場 合には，副反応として還元反応も進行する. ${ }^{9)}$ 筆者 らは，それら有毒な試薬を用いない安全で環境に配 慮したラジカル反応の開発を目的とした研究を展開 している.

最近，筆者らはラジカル開始剤としてトリエチル ホランを用いたオキシムエーテル 1 の分子間炭素ラ ジカル付加反応がスズヒドリド非存在下でも進行す

神戸薬科大学（†658-8558 神戸市東灘区本山北町 419-1)

e-mail: masa-u@ kobepharma-u.ac.jp

*本総説は, 平成 15 年度日本薬学会近畿支部奨励賞の

受賞を記念して記述したものである。
ることを見出した (Scheme 1).10,11)

本反応は, トリエチルボランから発生したエチル ラジカルがヨウ素原子移動反応を経由してアルキル ラジカルに変換される. このアルキルラジカルが, トリエチルボランにより活性化されたオキシムエー テルに付加する. その後, 生成したアミニルラジカ ルとトリエチルボランが反応し, エチルラジカルの 再生を伴い, ラジカル連鎖反応が進行する. このよ うにトリエチルボランはラジカル開始剤のみでな く, ルイス酸やラジカル停止剂としても働き, オキ シムエーテル基の活性化とラジカル連鎖反応の進行 を促進していることを見出した（Fig. 1).さらに， 筆者らは, 本反応を立体選択的な炭素ラジカル付加 反応に展開するために，基質としてオキシムエーテ ル $3^{12)}$ やニトロン $5^{13)}$ を用いて,$\alpha$-アミノ酸の不

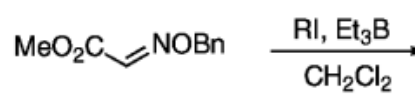

1

Scheme 1. Radical Addition via Iodine Atom-Transfer 


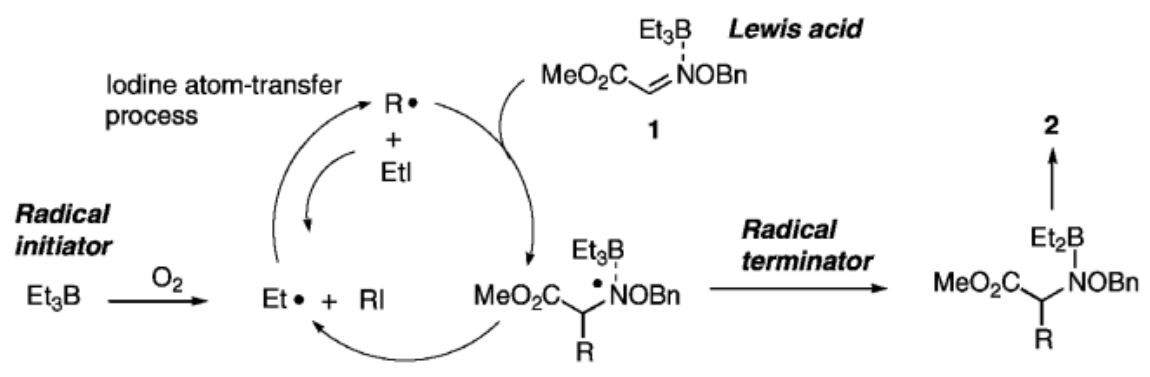

Fig. 1. Possible Reaction Pathway

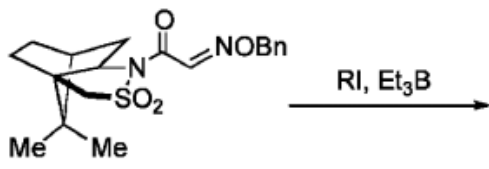

3
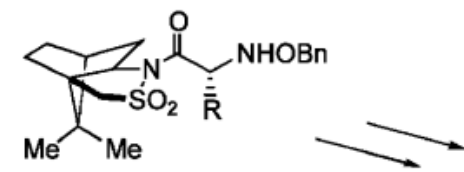

4<smiles>[R]C(N)C(=O)O</smiles>

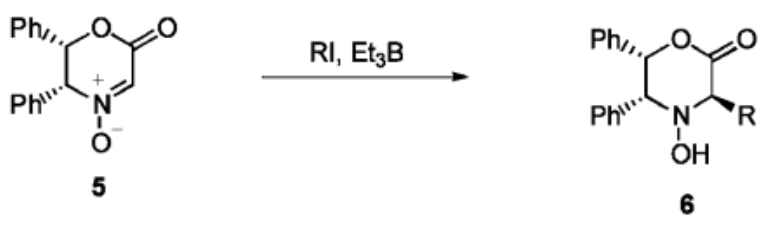

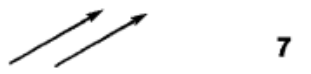

Scheme 2. Diastereoselective Radical Addition Reaction

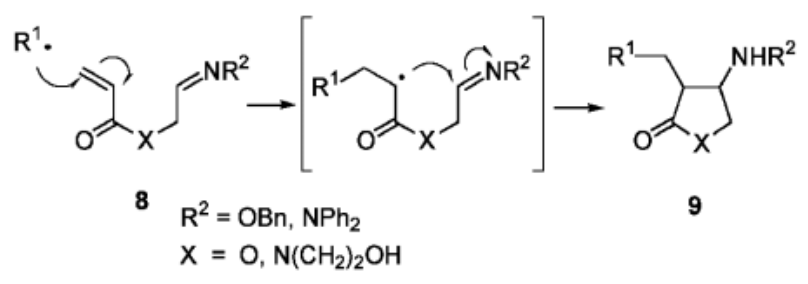

Scheme 3. Tandem Radical Addition-Cyclization Reaction

斉合成を行った（Scheme 2)。これまでに，ニトロ ンのラジカル反応の例としては, ラジカル捕獲剤と しての反応しか知られておらず，本反応はニトロン をラジカル受容体として合成反応に利用した最初の 研究である。

さらに，分子間反応と分子内反応を組み合わせた 反応として，2つの炭素一炭素結合を一挙に形成す るタンデム型ラジカル付加一閉環反応を開発した (Scheme 3).14) また, 水の生成を伴うイミンの形成 とラジカル反応をワンポットで行う $\alpha$-アミノ酸類 のワンポット合成の開発にも成功している. ${ }^{15)}$

筆者らは, 前述の研究とともにラジカル種が水に 対して安定であることに着目し, 安価で安全である 水を溶媒として用いた水中炭素一炭素結合形成ラジ
カル反応の開発研究も行っている. 本稿では, 水溶 媒中でラジカル開始剤としてトリエチルボランや亜 鉛を用いたイミン類への分子間炭素ラジカル付加反 応の開発と 1 電子移動型ラジカル開始剤としてイン ジウムを用いたラジカル反応の開発について述べる.

2. トリエチルボランを用いたイミン類への水中 ラジカル付加反応

一般に, 中性炭素ラジカルは水に対して安定であ るため, 水中でのラジカル反応の開発が期待されて いる. 16-23)

筆者らは，始めにラジカル開始剤として $\mathrm{Et}_{3} \mathrm{~B}$ を 用いて, 種々のイミン類への水中炭素ラジカル付加 反応を検討した. ${ }^{24)}$ 水に可溶なカルボキシル基を有 するオキシムエーテル 10 へのイソプロピルラジカ ル付加反応を検討したところ, 反応は 10 分で終了 し, 定量的に目的のイソプロピル体 11a が得られた (Scheme 4). 次に, オキシムエーテル 1, オキシム 12, ヒドラゾン 14, ニトロン 16 など様々なイミン 類への水中炭素ラジカル付加反応を検討した。 その 結果，基質により反応性が異なるものの，いずれの 場合も目的の付加体が得られることが判明した。一 般に, イミン類は水に不安定と考えられているた 
め，その水中反応はほとんど研究されていなかっ た．本反応のように水中でも比較的安定なイミンを 用いれば，目的の水中ラジカル反応が効率的に進行 することを初めて明らかにした。

次に, 本反応を $\alpha$-アミノ酸類の水中ワンポット 合成に応用した。グリオキシル酸水和物 $\mathbf{1 8}$, $\mathrm{BnONH}_{2} \cdot \mathrm{HCl}, \mathrm{RI}$ の 3 成分を用いて反応を検討し たところ，水中でもオキシムエーテルが生成し，そ の後ラジカル反応を行うことにより, 目的の $\alpha-ア$ ミノ酸誘導体 11a一d が得られた（Scheme 5)。

\section{3. 亜鉛を用いたイミン類への水中ラジカル付加} 反応

現在，ラジカル反応の分野において，スズヒドリ ドを用いない原子移動反応や 1 電子移動反応の開発 が望まれている. ${ }^{25-27)}$ 著者らは金属亜鉛の 1 電子 移動能に着目し, イミン類の水中ラジカル付加反応

$$
\underset{10}{\mathrm{HO}_{2} \mathrm{C}}=\mathrm{NOBn} \underset{\mathrm{H}_{2} \mathrm{O}, 20^{\circ} \mathrm{C}, 10 \mathrm{~min}}{\stackrel{i-\mathrm{Prl}_{1} \mathrm{Et}_{3} \mathrm{~B} \text { in hexane }}{\longrightarrow}}
$$$$
\underset{1}{\mathrm{MeO}_{2} \mathrm{C}}=\mathrm{NOBn} \underset{\mathrm{H}_{2} \mathrm{O}-\mathrm{MeOH}, 20^{\circ} \mathrm{C}, 2 \mathrm{~h}}{\stackrel{i-\mathrm{Prl}, \mathrm{Et}_{3} \mathrm{~B} \text { in hexane }}{\longrightarrow}}
$$<smiles>COC(/C=N/O)OC</smiles>

12

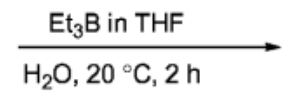

$\mathrm{MeO}_{2} \mathrm{C}_{\mathrm{Et}} \mathrm{NHOH}$ $13(55 \%)$<smiles>COC(=O)C=Nc1ccccc1</smiles>

14

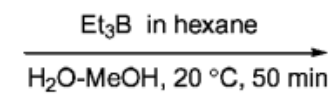<smiles>CCC(C(C)OC)N(CC)CC</smiles><smiles>CC(=O)C=[N+]([O-])c1ccccc1</smiles>

16
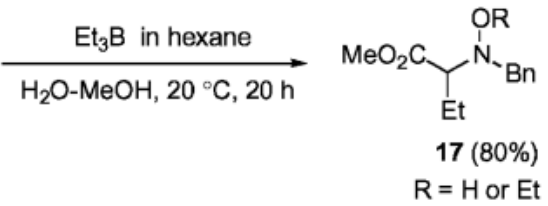

Scheme 4. Et ${ }_{3} \mathrm{~B}-\mathrm{Mediated}$ Radical Addition to Imine Derivatives in Water
を検討した。スルホニルイミン 19 を少量のジクロ ロメタンに溶かし，ヨウ化アルキルと亜鉛を加え， 室温で激しく攪汼しながら, 飽和塩化アンモニウム 水溶液を 15 分かけて滴下した。 その結果，イソプ ロピルやシクロヘキシルなど二級のアルキルラジカ ルとの反応では，良好な収率で，目的の付加体 $\mathbf{2 0}$ が得られた.この時, 副生成物として少量の還元体 21 も生成した（Table 1, entry 1-3)。また, 嵩高 い三級の $t$ - ブチルラジカルとも速やかに反応し, 目的の付加体が 66\%の収率で得られた（entry 4)。

しかし, 不安定な一級のメチルラジカルとの反応で は目的のメチル体は全く得られず，還元体が $16 \%$ の収率で得られた（entry 5)。アルキル付加体 20 の生成経路に関しては，ヨウ化アルキルと亜鉛から アルキルラジカルが発生し, スルホニルイミンに付 加し, 生成したアミニルラジカルの亜鉛による 1 電 子還元，プロトネーションを経て付加体 $\mathbf{2 0}$ が得ら れたと考えられる。 また, 還元体の生成経路に関し ては，スルホニルイミン 19 が带鉛により直接還元 され，還元体 21 が得られたと考えられる（Fig. 2) . ${ }^{28)}$

次に, 亜鉛によるカンファースルタムを有するオ キシムエーテル 3 及びヒドラゾン 22 への立体選択 的水中ラジカル付加反応を検討した（Scheme 6).

Table 1. Zinc-Mediated Alkyl Radical Addition to $N$ Sufonylimine

\begin{tabular}{|c|c|c|c|}
\hline & & & \\
\hline \multirow{2}{*}{ Entry $^{a)}$} & \multirow{2}{*}{$\mathrm{R}$} & \multicolumn{2}{|c|}{ Yield (\%) } \\
\hline & & 20 & 21 \\
\hline 1 & $i$-Pr & 73 & 8 \\
\hline 2 & c-Pentyl & 64 & 18 \\
\hline 3 & $s$-Bu & 56 & 10 \\
\hline 4 & $t-\mathrm{Bu}$ & 66 & 20 \\
\hline 5 & $\mathrm{Me}$ & 0 & 16 \\
\hline
\end{tabular}

a) Reactions were carried out with RI (5 equiv.) and zinc (7 equiv.).b) Isolated yield.<smiles>O=C(O)C(O)[18O]</smiles>

18

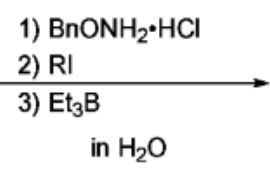<smiles>[14CH2]C(N[13CH]Cc1ccccc1)C(=O)O</smiles>

a: $\mathbf{R}=i-\operatorname{Pr}(97 \%)$

b: $\mathrm{R}=\mathrm{c}-\mathrm{Hexyl}(99 \%)$

c: $\mathrm{R}=\mathrm{s}-\mathrm{Bu}(95 \%)$

d: $R=c-$ Pentyl $(97 \%)$

Scheme 5. One-Pot Synthesis of $\alpha$-Amino Acids in Water 


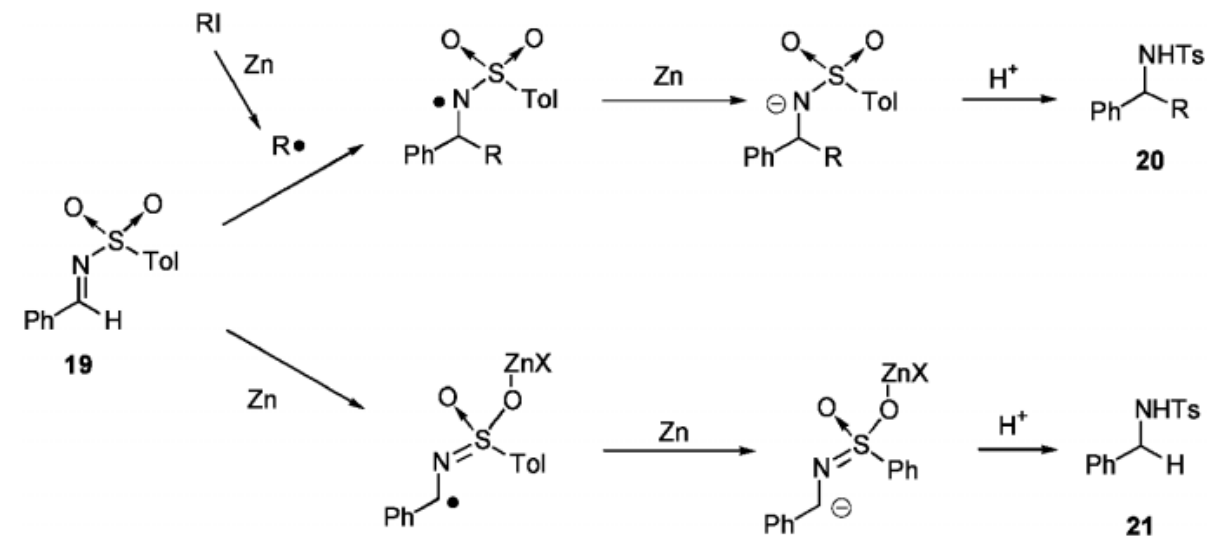

Fig. 2. Possible Reaction Pathway
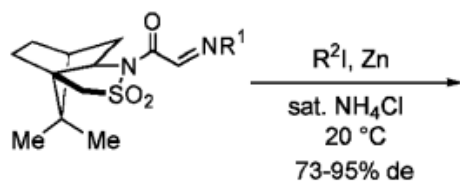

3: $\mathrm{R}^{1}=\mathrm{OBn}$,

22: $\mathrm{R}^{1}=\mathrm{NPh}_{2}$

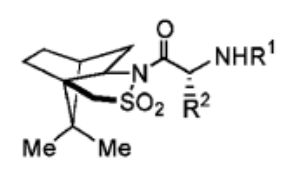

4: $\mathrm{R}^{1}=\mathrm{OBn}$,

23: $\mathrm{R}^{1}=\mathrm{NPh}_{2}$

Scheme 6. Zinc-Mediated Diastereoselective Radical Addition in Water

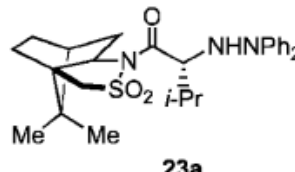

23a

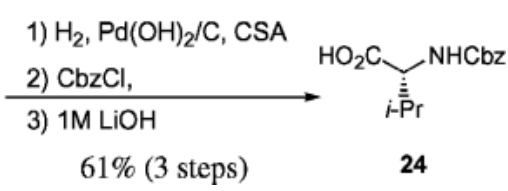

Scheme 7. Conversion into $N$-cbz-Valine

その結果，イミン部分の還元は起こらず，目的のラ ジカル反応が速やかに進行し, 立体選択的に付加体 が得られた. 次に, 得られた付加体 23a を加水素分 解による脱ジフェニルアミノ化，アミノ基の保護, 加水分解を経てバリン誘導体 $\mathbf{2 4}$ へ変換し， $\alpha$-アミ ノ酸の不斉合成を達成した（Scheme 7).29)

\section{4. インジウムを用いた水中ラジカル付加反応}

インジウムはアルカリ金属やアルカリ土類金属に 匹敵するほどの低い第一イオン化ポテンシャルを有 しており，水中でも安定な金属である. ${ }^{25-27,30)}$ その ため，インジウムを用いた水中反応は数多く報告さ れているが，その多くがアリルインジウム試薬を活 性種としたカルボニル化合物のアリル化反応である.

そこで, 筆者らはインジウムの 1 電子移動能に着 目し，水中で 1 電子移動により活性化されていない ヨウ化アルキルにおいてもアルキルラジカルを発生

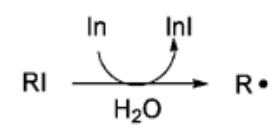

Scheme 8. Indium-Mediated Generation of Alkyl Radicals

させることができるのではないかと考え，本研究に 着手した（Scheme 8).

4-1. インジウムを用いたイミン類及び電子不足 オレフィンへの水中炭素ラジカル付加反応始め に，インジウムのラジカル開始剤としての効果を確 かめるため, これまでの筆者らの研究でラジカル反 応に対して高い反応性を示したオキシムエーテル 1 及びヒドラゾン 14 ヘのイソプロピルラジカル付加 反応を検討した. ${ }^{31)}$ まず，水一ジクロロメタン混合 溶媒中, オキシムエーテルへのイソプロピルラジカ ル付加反応を行ったところ, 反応終了には長時間を 要したが，目的の付加体 $\mathbf{2 a}$ が 76\%の収率で得られ た (Table 2, entry 1)。興味深いことに, 水の非存 在下では反応は全く進行せず，反応の進行のために は水が必須であることが判明した（entry 2)。ま た，溶媒を水一メタノール均一系混合溶媒に変えて 反応を行うと, 反応時間が大幅に短縮された（entry 3)。さらに，ラジカル捕捉剤として有名なガル ビノキシルフリーラジカルを添加すると反応が進行 しなかったことから，本反応がラジカルを経由して 進行していることが示唆された (entry 4). また, ヒドラゾン 14 を基質としてイソプロピルラジカル 付加反応を行ったところ, 高収率で目的の付加体 15aが得られた。 ヒドラゾンはオキシムエーテルに 比べて加水分解を受けにくく, そのため, 収率良く 
Table 2. Indium-Mediated Isopropyl Radical Addition to Oxime Ether $\mathbf{1}$ and Hydrazone 14

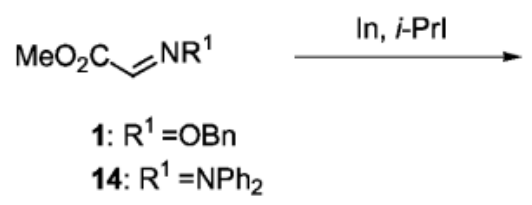<smiles>[R]NC([PH])C(=O)OC</smiles>

1: $R^{1}=\mathrm{OBn}$
14: $\mathrm{R}^{1}=\mathrm{NPh}$

2a: $\mathrm{R}^{1}=\mathrm{OBn}$

15a: $\mathrm{R}^{1}=\mathrm{NPh}_{2}$

\begin{tabular}{cclccc}
\hline \hline Entry & $\mathrm{R}^{1}$ & \multicolumn{1}{c}{ Solvent } & Product & Time (h) & Vield (\%) $^{a)}$ \\
\hline $1^{b)}$ & $\mathrm{OBn}$ & $\mathrm{H}_{2} \mathrm{O}-\mathrm{CH}_{2} \mathrm{Cl}_{2}$ & $\mathbf{2 a}$ & 22 & 76 \\
$2^{b)}$ & $\mathrm{OBn}$ & $\mathrm{CH}_{2} \mathrm{Cl}_{2}$ & $\mathbf{2 a}$ & 24 & $\mathrm{NR}$ \\
$3^{c)}$ & $\mathrm{OBn}$ & $\mathrm{H}_{2} \mathrm{O}-\mathrm{MeOH}$ & $\mathbf{2 a}$ & 0.5 & 74 \\
$4^{d)}$ & $\mathrm{OBn}$ & $\mathrm{H}_{2} \mathrm{O}-\mathrm{MeOH}$ & $\mathbf{2 a}$ & 0.5 & $\mathrm{NR}$ \\
$5^{e)}$ & $\mathrm{NPh}_{2}$ & $\mathrm{H}_{2} \mathrm{O}-\mathrm{MeOH}$ & $\mathbf{1 5 a}$ & 1 & 98 \\
\hline
\end{tabular}

a) Isolated yield. $b$ ) Reactions were carried out with $i$ - $\operatorname{PrI}(5$ equiv. $\times 2)$ and indium (7 equiv.). c) Reaction was carried out with $i$-PrI (4 equiv. $\times 2)$ and indium (7 equiv.). d) Reaction was carried out with galvinoxyl free radical ( 2 equiv.), $i$-PrI $(4$ equiv. $\times 2)$ and indium ( 7 equiv.). $e$ ) Reaction was carried out with $i$-PrI (5 equiv. $\times 2$ ) and indium (7 equiv.).

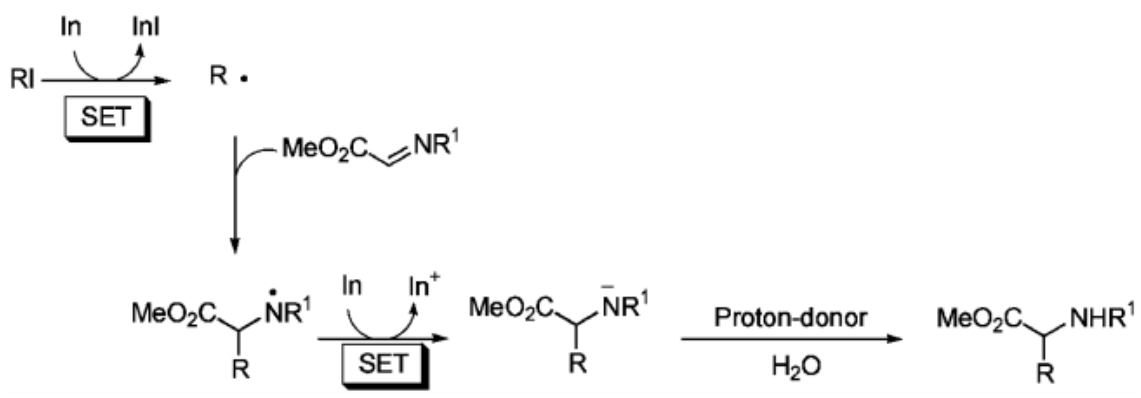

Fig. 3. Possible Reaction Pathway

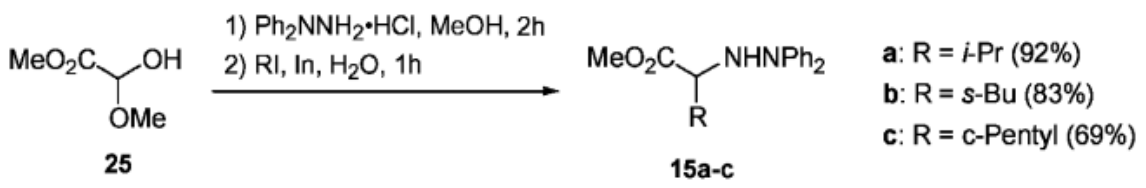

Scheme 9. One-Pot Reaction

反応が進行したと考えられる.

本反応の反応経路は，以下のように考えられる (Fig. 3).インジウムから RIへの 1 電子移動によ り発生した炭素ラジカルがイミンに付加し, アミニ ルラジカルが生成する。 さらにインジウムからの 1 電子移動によりアミドアニオンとなり，水と反応し て目的の生成物が得られる. 水はプロトン供給源と して㗢くとともに, インジウムの活性化にも有効に 働いていると考えられる.

次に, 本反応をワンポット反応に展開した。 ワン ポット反応は一般に抽出・精製の手間を省けるばか りでなく, 有機溶媒の使用量を減らせるなどグリー
ンケミストリーの観点から望ましいとされている. グリオキシル酸誘導体 $\mathbf{2 5}$, ジフェニルヒドラジン 塩酸塩及びヨウ化アルキルの 3 成分を用いた $\alpha$-ア ミノ酸のワンポット合成を検討した結果, 水の脱離 を伴うヒドラゾンの生成と, 続くラジカル反応を経 て目的の $\alpha$-アミノ酸誘導体 $\mathbf{1 5 a}-\mathbf{c}$ が収率良く得ら れた（Scheme 9).

さらに, 電子不足なオレフィンとしてフェニルビ ニルスルホン $26 へ$ Michael 型ラジカル付加反応 を検討したところ，目的の付加体 $\mathbf{2 7} \mathbf{a}$ - $\mathbf{d}$ が収率良 く得られ, ラジカル開始剤としてのインジウムの汎 用性が実証された（Scheme 10）。また，インジウ 


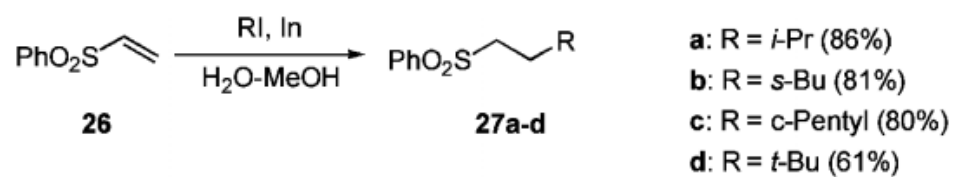

Scheme 10. Indium-Mediated Michael-Type Reaction

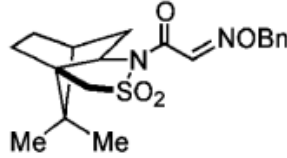

3

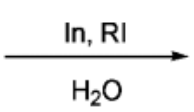

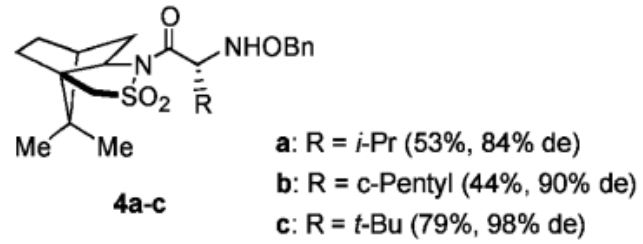

c: $R=t-B u(79 \%, 98 \%$ de $)$

Scheme 11. Indium-Mediated Diastereoselective Radical Addition to Oxime Ether

ムは亜鉛とは異なり，ラジカルの発生に酸性条件を 必要とせず, しかもイミンの還元反応などの副反応 は起こらない点で優れている.

4-2. インジウムを用いた立体選択的水中ラジカ ル付加反応次に, 本反応を立体選択的なラジカ ル反応に展開した。一般にラジカル反応の立体制御 は難しく, その開発は重要課題の 1 つである. ${ }^{8,32}$ 不斉補助基としてカンファースルタムを有するオキ シムエーテル 3 ヘのアルキルラジカル付加反応を行 つたところ, 目的の付加体 $\mathbf{4 a -} \mathbf{c}$ が高い立体選択性 で得られた (Scheme 11). 特に, 嵩高い三級の $t$ ブチルラジカルとの反応では, 最も良い収率及び立 体選択性で付加体 $\mathbf{4 c}$ が得られた。 また，アリルイ ンジウムを活性種として用いたオキシムエーテル 3 への立体選択的水中アリル化反応にも成功した. ${ }^{33)}$

4-3. インジウムを用いたタンデム型水中ラジカ ル反応次に, 水中で 2 つ炭素-炭素結合形成 することを目的としてタンデム反応の開発に着手し た。一度に数カ所の結合を形成するタンデム反応 は, 環境的観点からも重要である. 始めに, 分子内 に $\alpha, \beta$ - 不飽和カルボニル基を有するオレフィン 28 を基質として, インジウム, ヨウ化イソプロピルに よる水中タンデム反応を検討した（Scheme 12）.

その結果, 付加-閉環-ヨウ素化が進行したヨウ化 物 29a が収率良く得られ, 同時に 1,4- 付加体 30a も少量生成した（Table 3, entry 1). また, 有機溶 媒としてジクロロメタンを共存させると, 反応時間 の延長が見られた。 さらに, 他のアルキルラジカル との反応も速やかに進行した (entry 3,4). ヨウ化 物 29 が得られたことから本反応はラジカル機構で
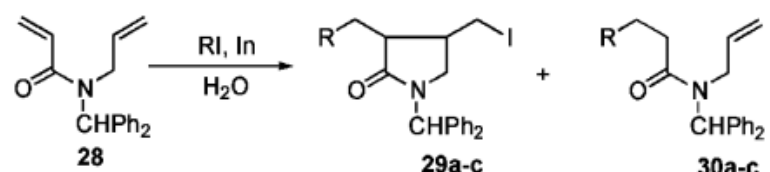

$\mathbf{a}: \mathbf{R}=i-\mathrm{Pr}, \mathbf{b}: \mathbf{R}=\mathrm{c}-\mathrm{Pentyl}, \mathbf{c}: \mathbf{R}=t-\mathrm{Bu}$

Scheme 12. Indium-Mediated Tandem Reaction in Water

進行していることが示唆される. 次に, 閉環体 29a の開環反応により付加体 30a が生成する可能性を検 証するため, 得られた閉環体 29a を水中, ヨウ化个 ソプロピルとインジウムで処理したが, ヨウ素の還 元や, 開環反応は起こらなかつた。これらの結果に 基づき反応経路を次のように考察した（Fig. 4).

始めに, インジウムからヨウ化アルキルへの 1 電 子移動により，アルキルラジカルが発生する。アル キルラジカルは求核的なラジカルであるため, 求電 子性の強い $\alpha, \beta$ - 不飽和カルボニル基に選択的に付 加し， $\alpha$-カルボニルラジカル $\mathbf{A}$ が生成し，その 後, 分子内に存在するオレフィンと反応することに より, 一級ラジカル B が生成する。一級ラジカル は不安定なため, 速やかに, ヨウ化アルキルに捕獲 され，アルキルラジカルの発生を伴い, 閉環体 29 が得られたと考えられる。 一方, 付加体 $\mathbf{3 0}$ の生成 経路に関しては，2つの経路が考えられる．すなわ ち， $\alpha$-カルボニルラジカル $\mathbf{A}$ がインジウムからの 1 電子移動を受け, カルボアニオン $\mathbf{C}$ が生成し, $\mathbf{3 0}$ が得られる経路と, 始めに発生したアルキルラジカ ルがインジウムからの 1 電子移動を受け, アルキル インジウム試薬が生成し, イオン的に共役付加反応 が起こる経路である。しかし, 水中で反応が進行し 
Table 3. Indium-Mediated Tandem Reaction of $\mathbf{2 8}$

\begin{tabular}{|c|c|c|c|c|c|}
\hline \multirow{2}{*}{ Entry } & \multirow{2}{*}{ RI } & \multirow{2}{*}{ Solvent } & \multirow{2}{*}{ Time (h) } & \multicolumn{2}{|c|}{ Yield $(\%)^{a)}$} \\
\hline & & & & $29 \mathbf{a}-\mathbf{c}^{b)}$ & $30 a-c$ \\
\hline $1^{c)}$ & $i$-PrI & $\mathrm{H}_{2} \mathrm{O}$ & 2 & $63(3.2: 1)$ & 13 \\
\hline $2^{c)}$ & $i$-PrI & $\mathrm{H}_{2} \mathrm{O}-\mathrm{CH}_{2} \mathrm{Cl}_{2}(4: 1)$ & 20 & $63(4.7: 1)$ & 21 \\
\hline $3^{c)}$ & $c$-Pentyl I & $\mathrm{H}_{2} \mathrm{O}$ & 2 & $65(4.0: 1)$ & 9 \\
\hline $4^{c)}$ & $t$-BuI & $\mathrm{H}_{2} \mathrm{O}$ & 2 & $38(3.6: 1)$ & 19 \\
\hline
\end{tabular}

a) Isolated yields. $b$ ) Ratio in parentheses is for trans: cis-selectivity of $\mathbf{2 9 a}-\mathbf{c}$; The trans: cis-selectivities were determined by ${ }^{1} \mathrm{H}$ NMR analysis. c) Reactions were carried out with RI (5 equiv. $\times 2$ ) and $\mathrm{In}\left(2\right.$ equiv.) in $\mathrm{H}_{2} \mathrm{O}$ at $20^{\circ} \mathrm{C}$.

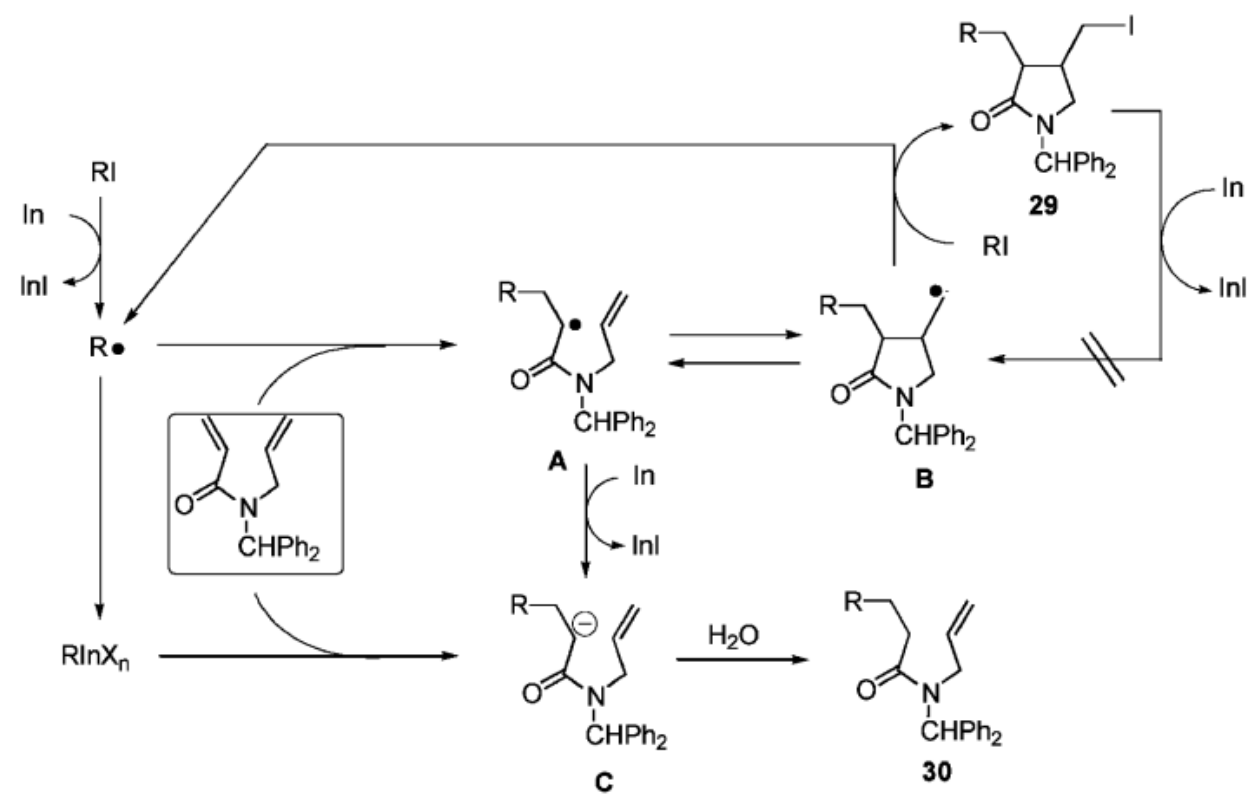

Fig. 4. Possible Reaction Pathway<smiles>C=CCN(Cc1ccccc1)S(=O)(=O)CC</smiles>

31<smiles>C=CN(C/C=N\P(=O)(O)OC)S(=O)(=O)OC</smiles>

33<smiles>[R]CC1C(CI)CN(Cc2ccccc2)S1(=O)=O</smiles>

32

a : $\mathrm{R}=i-\operatorname{Pr}(81 \%$, trans $:$ cis $=1: 1.4)$

b : $R=$ c-Pentyl $(84 \%$, trans : cis $=1: 1.3)$

c : $R=t-B u(79 \%$, trans : cis $=1: 2.0)$<smiles>[R]CC1C(NNc2ccccc2)CN(Cc2ccccc2)S1(=O)=O</smiles>

34 a : $\mathrm{R}=i-\operatorname{Pr}(93 \%$, trans : cis $=1: 1.2)$

b : $\mathbf{R}=$ c-Pentyl $(86 \%$, trans : cis $=1: 1.1)$

c : $\mathrm{R}=t-\mathrm{Bu}(42 \%$, trans : cis $=1: 1.6)$

Scheme 13. Tandem Radical Reaction of Sulfonamide

ていること，及び $t$ - ブチル基の付加も容易に進行 していることから, 現在のところ, 前者のラジカル 反応経路で進行していると考えられる.

さらに, 先の Michael 型ラジカル付加反応で高い
反応性を示したビニルスルホンを分子内に有するオ レフィン 31 を基質として, タンデム反応を検討し た。 その結果, 目的の閉環体 $\mathbf{3 2}$ のみが高収率で得 られた（Scheme 13）。本反応の特徵としては，2つ 
の炭素一炭素結合と 1 つの炭素一ヨウ素結合を一段 階で構築する点が上げられる，さらに，ヒドラゾン を有する基質 33 のタンデム型付加一閉環反応も速 やかに進行し，付加一閉環体 $\mathbf{3 4}$ が収率良く得られ た. ${ }^{34)}$

\section{5. おわりに}

筆者らは，環境調和型合成反応として水中ラジカ ル反応による炭素一炭素結合形成反応の開発に成功 した. ラジカル開始剤としてトリエチルボラン, 亜 鉛及びインジウムを用いてイミン類への炭素ラジカ ル付加反応を検討し, 立体選択的反応やワンポット 反応に展開した。特に, 筆者らはインジウムが水中 で 1 電子移動型ラジカル開始剤と働くことを見出 し, 様々な水中ラジカル反応に展開してきた。溶媒 としての水の利用は単に安価で無害なだけでなく, 保護一脱保護過程の省略や水中でしか起こらないユ ニークな新しい反応の発見につながると期待してい る.

謝辞本研究を行うに当たり，ご指導とご支援 を賜りました神戸薬科大学内藤猛章教授に厚くお礼 申し上げます。また，本研究を推進するに当たり， ご協力いただきました共同研究者の皆様に深く感謝 いたします，なお，本研究は神戸薬科大学及び文部 科学省科学研究費「若手研究 (B)」のご支援により 行われたものであり，併せて感謝いたします。

\section{REFERENCES}

1) Fossey J., Lefort D., Sorba J., “Free Radicals in Organic Chemistry." translated by Lomas J., John Wiley \& Sons, New York, 1995.

2) Ryu I., Sonoda N., Curran D. P., Chem. Rev., 96, 177-194 (1996).

3) Snider B. B., Chem. Rev., 96, 339-363 (1996).

4) Giese B., Kopping B., Göbel T., Dickhaut J., Thoma G., Kulicke K. J., Trach F., Org. React. (N.Y.), 48, 301-856 (1996).

5) Renaud P., Gerster M., Angew. Chem., Int. Ed. Engl., 37, 2562-2579 (1998).

6) Sibi M. P., Porter N. A., Acc. Chem. Res., 32, 163-171 (1999).

7) Bowman W. R., Bridge C. F., Brookes P., J. Chem. Soc., Perkin Trans. 1, 1-14 (2000).
8) "Radicals in Organic Synthesis" Vol. 1 and 2, eds. by Renaud P., Sibi M. P., Wiley-VCH, Weinheim, 2001.

9) Ueda M., Miyabe H., Namba M., Nakabayashi T., Naito T., Tetrahedron Lett., 43, 43694371 (2002).

10) Miyabe H., Ueda M., Yoshioka N., Naito T., Synlett, 465-467 (1999).

11) Miyabe H., Yoshioka N., Ueda M., Naito T., J. Chem. Soc., Perkin Trans. 1, 3659-3660 (1998).

12) Miyabe H., Ushiro C., Ueda M., Yamakawa K., Naito T., J. Org. Chem., 65, 176-185 (2000).

13) Ueda M., Miyabe H., Teramachi M., Miyata O., Naito T., Chem. Commun., 426-427 (2003).

14) Miyabe H., Ueda M., Fujii K., Nishimura A., Naito T., J. Org. Chem., 68, 5618-5626 (2003).

15) Miyabe H., Ueda M., Yoshioka N., Yamakawa K., Naito T., Tetrahedron, 56, 2413-2420 (2000).

16) Yorimitsu H., Nakamura T., Shinokubo H., Oshima K., J. Org. Chem., 63, 8604-8605 (1998).

17) Yorimitsu H., Nakamura T., Shinokubo H., Oshima K., Omoto K., Fujimoto H., J. Am. Chem. Soc., 122, 11043-11047 (2000).

18) Yorimitsu H., Shinokubo H., Oshima K., Synlett, 674-686 (2002).

19) Kita Y., Nambu H., Ramesh N. G., Anikumar G., Matsugi M., Org. Lett., 3, 1157-1160 (2001).

20) Nambu H., Anikumar G., Matsugi M., Kita Y., Tetrahedron, 59, 77-85 (2003).

21) Nambu H., Hata K., Matsugi M., Kita Y., Chem. Commun., 1082-1083 (2002).

22) Sugiura M., Hagio H., Kobayashi S., Chem. Lett., 32, 898-899 (2003).

23) Khan T. A., Tripoli R., Crawford J. J., Martin C. G., Murphy J. A., Org Lett., 5, 29712974 (2003).

24) Miyabe H., Ueda M., Naito T., J. Org. Chem., 65, 5043-5047 (2000).

25) Li C. J., Chem. Rev,. 93, 2023-2035 (1993).

26) Lubineau R., Angé J., Queneau Y., Synthesis, 741-760 (1994).

27) Li C. J., Tetrahedron, 52, 5643-5668 (1996). 
28) Miyabe H., Ueda M., Naito T., Chem. Commun., 2059-2060 (2000).

29) Ueda M., Miyabe H., Nishimura A., Sugino H., Naito T., Tetrahedron: Asymmetry, 14, 2857-2859 (2003).

30) Podlech J., Maier T. C., Synthesis, 633-655 (2003).

31) Miyabe H., Ueda M., Nishimura A., Naito T., Org. Lett., 4, 131-134 (2002).
32) "Stereochemistry of Radical Reactions: Concepts, Guidelines, and Synthetic Applications," eds. by Curran D. P., Porter N. A., Giese B., VCH, Weinheim, 1996.

33) Miyabe H., Nishimura A., Ueda M., Naito T., Chem. Commun., 1454-1455 (2002).

34) Ueda M., Miyabe H., Nishimura A., Miyata O., Takemoto Y., Naito T., Org. Lett., 5, 3835-3838 (2003). 